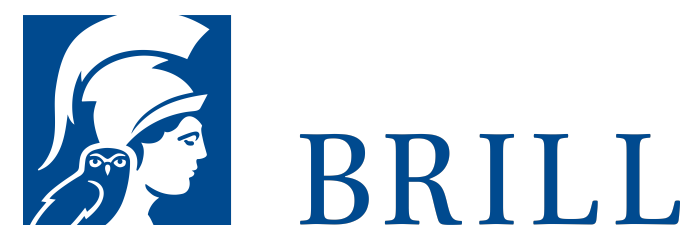

\title{
Von der Stadt zur urbanen Gesellschaft
}

Jacob Burckhardt und Henri Lefebvre

Author: Kurt Meyer

Ein Kulturhistoriker des 19. Jahrhunderts, Jacob Burckhardt, und ein Städteforscher des 20. Jahrhunderts, Henri Lefebvre, versuchen den rasanten Wandel der Städte zu verstehen. Der Ältere hat sich noch an der Buntheit der europäischen historischen Stadt erfreut, sich dann den grossen europäischen Stadtkulturen zugewandt, dem Florenz der Renaissance und der antiken Polis. Der Jüngere kommt aus einem Dorf in den Pyrenäen nach Paris und trifft dort auf eine chaotische periphere Stadtlandschaft. Die Wiege des Reichtums, die historische Stadt, ist aufgesprengt; im heutigen abstrakten Urbanraum einer Global City dominieren die Banken, Geschäftszentren, Flughäfen, Informations- und Entscheidungszentren. Der Prozess der masslosen Urbanisierung, der Verwüstung des Raumes, verlangt nach einer Theorie des Raumes. Der Kontrast zwischen der kulturhistorischen Sichtweise und einer modernen Theoriebildung ist stimulierend.

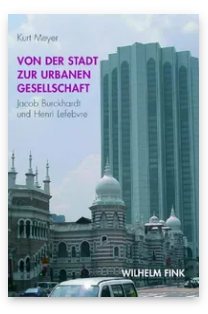

Pages: 408

Seiten

Language:

German

Subjects:

Cultural History,

Literature and

Cultural Studies

Publisher: Brill |

Fink

E-Book (PDF)

Released online:

o7 Oct 2019

ISBN: $978-3-$

8467-4533-5

List price

USD $\$ 84.00$

Paperback

Publication date:

04 Oct 2007

ISBN: 978-3-

7705-4533-9

List price

USD $\$ 84.00$ 
For more information see brill.com

Order information: Order online at brill.com +44330 333 0049 | customerservices@brill.com Submission information: brill.com/authors

Titles published by Brill | Fink, Brill | mentis or Brill | Schöningh: +49(o)715413279216| brill@brocom.de 